The investigations are being continued. Other methods of control are also being tried.

H. D. JORDAN

West African Rice Research Station,

Rokupr, Sierra Leone.

Nov. 30.

\section{Deoxyribonucleic Acid and Ribonucleic Acid in Hyphal Cells of Higher Fungi}

THE importance of deoxyribonucleic acid (DNA) and ribonucleic acid (RNA) in the physiology of a cell is very great. Very little work on cells of fungal hyphæ seems to have been done. For this purpose, very young (2-3 days old) subcultures of Polyporus ostreiformis, Polyporus adustus, Polyporus gilvus and Marasmius campanella were taken; they were fixed and stained for 15-20 min. by the method of Unna as adapted by Brachet ${ }^{1}$. The small resting nuclei of the homogeneous unexpanded type of Pinto Lopes ${ }^{2}$ became very prominent in pyronin-stained cytoplasm; nucleolus and chromatin, combined at the centre into a homogeneous mass, took brilliant green stain (DNA) surrounded by pink hyloplasm (RNA), and finally by a green outline (Fig. 1). The nucleolus, according to Brachet ${ }^{3}$ and Caspersson ${ }^{4}$, is believed to be composed mainly of ribonucleoproteins, and $\mathrm{Fujii}^{5}$ holds that zinc, in addition, is present in nucleoli and that, upon the initiation of mitosis, zinc passes into chromosomes and possibly also into prometaphase spindle.

Nuclei of fungal hyphæ being extremely small, Unna staining will be of additional help in distinguishing the haploid from the diploid states by the respective sizes of the nuclei.

DNA in the nuclei is rather of a transitory nature, hence all the nuclei in a mycelium do not take the same prominent methyl green stain. There are differences of opinion as to whether DNA becomes prominent in the nuclei immediately before mitosis or during the early stages of prophase.

In Cyanophyceae the presence of a distinct nucleus (central body) is a matter of dispute. Biswas ${ }^{6}$, working with Oscillatoria and Calothrix species of this group, could not obtain the methyl green stain of the central body (that is, the presence of DNA), and he thinks that DNA has not been highly polymerized in this lower group. Kurnick ${ }^{7}$ holds that DNA is in a highly polymerized state and RNA is in a non-polymerized state, and therefore DNA takes on methyl green stain and RNA takes on pyronin stain. The-specific character of these two dyes for the two nucleic acids has been confirmed by Sharma and Bhattacharje $e^{8}$ working on different plant materials (Allium cepa, Zephyranthus longifolia, etc.).

Evidence has been brought forward to show that ribonucleic acid plays an important pert in protein synthesis', while accumulation of data by S. Zamenhof ${ }^{10}$ strongly suggests that the composition of deoxy-

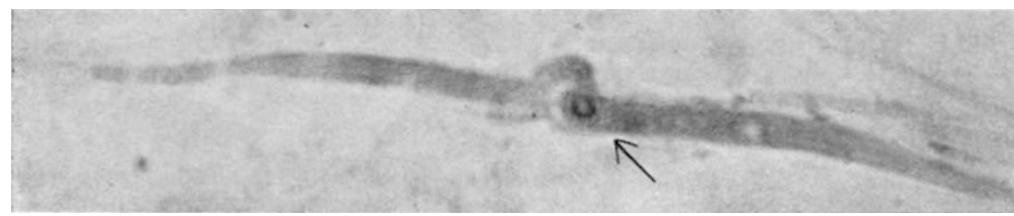

Fig. 1. Marasmius campella. Arrow shows the nucleus close to the clamp connexion. $(\times 1,800)$ ribonucleic acid is independent of the environment and, as such, it seems to be a hereditary determinant.

It is hoped that further work will gradually clarify these points.

Note added in proof. From Ledoux's (Nature, 175, 258 ; 1955) recent communication, it appears that cellular multiplication of proliferating cells in carcinomata of mouse and rat can be modified through changes in the level of ribonucleic acid by the administration of ribonuclease both in vitro and in vivo experiments with animals. This, he holds, compares favourably with the results obtained with amphibian eggs and with those of Brachet (Nature, 174,876 ; 1954) with onion root tips; ribonuclease diffusing across the cell membrane has a very clear anti-mitotic effect.

Carmichael Medical College.

S. R. Bose

Botanical Laboratory,

Calcutta, India. Feb. 28.

${ }^{2}$ Brachet, J., Quart. J. Micro. Sci. (Third Series, No. 25), 94, 1 (1953).

2 Pinto Lopes, J., Portug. Acta Biol., (A), 2, 198 (1948).

${ }^{3}$ Brachet, J., Arch. Biol., 53, 207 (1942).

- Caspersson, T., Symp. Soc. Exp. Biol., 1, 127 (1947).

${ }^{5}$ Fujii, T., Nature, 174, 1108 (1954).

- Biswas, B. B., Curr. Sci., 22, 346 (1953).

' Kurnick, N. B., J. Gen. Physiol., 33, 243 (1950).

- Sharma, A. K., and Bhattacharjee, D., Nature, 169, 417 (1952).

- Gale, E. F., and Folkes, J. P., Nature, 173, 1227 (1954).

${ }^{10}$ Zamenhof, S., in "Phosphoru's Metabolism", 2, 301 (1952); Nature, 165, 756 (1950); Nature, 174, 306 (1954).

\section{Effect of Sodium Chloride on Softening and Carbohydrate Changes of Date Fruits}

Usually Egyptians prefer to consume the date fruits when they are soft (ripe). This softening is either reached normally when the fruits are still on the tree, or it may be hastened by pretreatment of the mature fruits with an aqueous solution of sodium chloride. The latter observation inspired us to study the effect of different concentrations of sodium chloride on the rate of softening of the date fruits as well as on the carbohydrate changes.

The date fruits used in this experiment were picked from one tree and were segregated into homogeneous batches according to the procedure previously suggested by Nada ${ }^{1}$. Only the fruits with the highest sugar content were used in the present experiment. These were divided into five equivalent lots, one of which was sliced and extracted in hot alcohol (seed excluded) and finally analysed for the initial carbohydrate fractions. The remaining lots were sterilized in 2 per cent hydrogen peroxide for five minutes, after which each of the lots was soaked for six hours in one of the following solutions : (1) distilled water, $(2),(3)$ and (4) solutions contrining 2,5 and 10 per cent sodium chloride respectively. At the expiry of this experimental period, the dates were again sterilized in hydrogen peroxide, rinsed well with sterile distilled water and finally blotted dry.

After this pretreatment each lot of dates was placed in a well-aerated dark chamber at temperature $30^{\circ} \mathrm{C}$, and the experiment continued for $60 \mathrm{hr}$., after which the softness of the fruits was compared and then they were analysed for their carbohydrate fractions.

It appeared that the dates that had been soaked in solutions 3 and 4 were completely soft; whereas 